\author{
Adrian Frazier* \\ National University of Ireland \\ English Department \\ Galway, Ireland
}

\title{
MEN AND BEAUTY
}

\begin{abstract}
This autobiographical essay in praise of Pat Sheeran, the Irish novelist, filmmaker, and scholar, addresses the following questions: "What is to be done with this newfound knowledge that in beauty, behind beauty, is nothing, the abyss, dust?" What forms of writing and living by men suffice in our period, when theory has exhausted the resources of cultural replenishment formerly available, yet death and purposeless still stare us in the face? By exploring the unusual and shamanistic character of Pat Sheeran, this essay explores how beauty, love, and art as male pursuits may still have value.
\end{abstract}

Key words: Pat Sheeran, novel, film, beauty, nothing, writing, death, purposeless, art

Pat Sheeran was a writer, filmmaker, and teacher at the National University of Ireland, Galway. In September 2001 he died of a heart attack. Four years earlier, not long after I arrived in Galway on a research fellowship, I found out what his other friends already knew. He had a wild genius for sincerity. (Indeed, as Kevin Barry remarked after his passing, Pat was so "boyishly sincere" he was sometimes baffled by university bureaucracy and its forms of politesse; "he had no other way than sincerity; he flew in under your radar." )

The evening began in this way: Pat Sheeran caught me by the arm in the crowds on Shop Street in Galway, and pulled me into a pub. The drinks

\footnotetext{
E-mail address for correspondence: adrian.frazier@nuigalway.ie
} 
were not yet drawn when he said that he was shattered; his mother had died. He had come into money and wanted to spend it as fast as possible. We should go eat the most expensive meal it was possible to eat in Galway, and drink until everything that had recently passed had been forgotten. Was I game?

I was game. As the waiter landed in front of us two saucers with a dozen oysters each, he told me about the film, "The Fifth Province." It was set in a place both within and supplementary to the Four Provinces of Ireland, a place in which the impossible always happens. Pat Sheeran explained that through transcendental meditation he had learned to travel to this other province, striding out of his body while his body slept. There was such a gleam in his eye as Yeats possibly had when he spoke of talking with the dead.

- So where do you go when you have these out-of-the-body experiences-rooms where ladies are lonely? But then you would wish you'd brought your body with you, wouldn't you?

For rambunctious combinations of the laddish and the elfin, Pat Sheeran had both a taste and a talent. He was good at getting out of bounds quickly and gaily, and for coming to grips with what could bring two people together in talk of what most mattered. As good a gossip as a very smart woman, Pat Sheeran soon established that we were both married, both parents of children in their twenties, both in love with the woman of our (different) dreams, both unhappy with the current orthodoxies of our profession, even with those elements that we ourselves in the past had helped to make orthodox, both trying to find a new way of writing that enabled us to allow ideas to arise out of and return to the both the dailiness and depths of our personal lives.

In his 1992 opening address to the Yeats Summer School, Pat Sheeran had made much of the importance of colonization to the understanding of Irish literature. Now he said he was tired of the "post-colonial racket." He had a theory (he always had "a theory") that British imperialism had enriched his life as an Irish person. He would not have things different from what they'd been. He had been left with both the English and the Irish languages. He had a great hook-up with America because of the Irish diaspora, he could take advantage of whatever was on offer in Britain just like a British person, and still he was a citizen of this little republic on the receiving end of EU transfer payments, a nation too small to do much harm to others. The bellyaching of middle-class academics-as if they were 
personally oppressed-annoyed him, as would any kind of bellyaching. The default setting for his mindset was joyousness.

We agreed, around the time that dessert arrived, that the pleasure of literature had been left so long unmentioned many did not know where to find it or how to experience it. Literature was a text you swatted up for exams on the crimes of the bourgeois, or the men, the white men, the straight men, or the imperial British, or the capitalist Americans. The quest for justice was indeed important, but we had forgotten to hold justice and beauty in a single thought (see: Yeats). Somehow, beauty had slipped our grasp and gone missing.

"Magic" was his own gadget - a way of using language that made reality include the dead and the ghosts of all earlier beliefs. I wanted to talk about beauty. A writer like Yeats would keep changing a poem in draft without respect to consistency of meaning. Finally, the poem would click into place, and nothing could again be changed. What is it that is perceived by the artist when he or she stands back with satisfaction...Perfecto! Yet it was difficult to talk about how a poem or story finds its own form, one that accommodates us to the un-alterability of a pseudo-statement, a statement that was not necessarily equivalent to the prior opinion of the author and one that was unavailable to disconfirmation. It was much harder to talk about beauty than about meaning, utility, power, or history. I was beginning to be boring. Pat's eyes were drifting off. Professors hate to be lectured by Professors. Indeed, so do other people.

About midnight, he took me out into the country. He pulled the car up under some oaks beside a massive front gate barring the way to a long drive. At the end of that drive, Pat explained, was the last Big House in Ireland to have been burned by the IRA. One day he would introduce me to the man who set fire to it. faery?

- Come along, we'll go for a walk. Have you ever, he asked, seen a

No, and I did not expect to do so this night. Like a round wheel of fire, he said they were, silently whooshing over the grass, and you rarely got to see them except through the corner of your eye, and then only in haunted places like this place, sometime after midnight. Quiet dropped upon us. The place was indeed somewhat spooky. The grasses were blowing in the nightwind, and moonlight was making the hills milky and frothy-looking. The serpentine drive went over a little bridge. Up from below came the weird variety of pitches and percussions $18^{\text {th }}$ century versifiers called the 
"purling of a little rill." Off to the side were grey masonry outbuildings around a yard. The drive circled up a hill, and we reached the front of the burned-out house. Above it, backlit clouds streamed across the sky, and you got a strange sensation when staring up the walls that they themselves were moving and the sky was still. This was the "Pat Sheeran effect." When you go with a seer to look for things that are not natural, they seem to be about to appear. But the walls did not move; the clouds moved, I reminded myself, and we turned back toward the car along the other route of the circular drive.

It led down towards a lake, and at one end of the lake one could make out a black grove of trees. The strangest sound began to come from that grove. It made your small hairs stand up-a kind of squawking, very raspy, and in waves of chorus upon chorus growing. As we came up to the trees there suddenly lifted from those branches one and then several and finally a whole flock of nesting herons. It was a rookery! Those were angry mother and father birds, protecting their big chicks. One could now see the nests of sticks. Perfectly natural explanation.

On the way back to Galway, Pat Sheeran remained silent, pleased with the night's epiphany.

\section{2}

A year later, my wife Cliodhna and I had dinner with Pat Sheeran and his life-companion and co-author Nina Witoszek. Together Nina and Pat write novels, films, and essays as "Nina Fitzpatrick" (a characteristic pun: Nina fits Patrick). They are transgendered soul-mates. He says that she is the male principle he had previously always needed-the structuring, intellectual, far-seeing, and purposeful intelligence. She says he is her Muse.

Some months earlier, Nina had had a tumor taken out of her stomach. For a while, she had been looking toward death. The four of us were talking of what death might be like, and could one really get up close to it, even pass across into it, prior to the moment of death itself. Or was it always an infinite distance from life, and wholly unimaginable? Nina and Pat were making a documentary about Irish funerary traditions, based on Nina's doctoral thesis, Talking to the Dead.

My belief, I admitted, is that I have died, and not once but many times. Some males have an overly active panic response. When something 
frightens such a man (an unstoppable rapid flow of blood does it for me), then his heart races and his breath stops. This overly active response then sets in. It sends a biochemical signal telling the heart to slow down, but it sends too powerful a signal, and instead of slowing down, the heart stops. So the bloodflow to the brain stops. The man turns greenish-white and faints. Some time later-from a few seconds to a minute-the phenomenon passes over, and the man slowly comes back to consciousness. During that spell when the heart is stopped, I believe that one is virtually dead.

On these wretched disabling occasions, I always have the same dream. I am falling down a corridor, a corridor that is not a vertical drop, but a slowly twisting angular fall. The speed of the fall is not so fast as if you had jumped off a building; it is a rapid downdrift, in which your arms swim and grab, and your feet cannot find any footing. Along the corridor are doors, and sometimes you can see into the rooms. Inside traumatic scenes are enacted by ill-assorted people from your past. You become aware that the corridor must have a bottom, and when you reach it, that will be the end of you. But every part of your body has become unbelievably heavy, as if you are in a centrifuge. Your hand weighs a ton; you strain to lift it, to hold it up in front of your face, as if to ward off evil. There is a blast of light, then more blasts. Now you find yourself rising above the scene in which you first fainted. There you are, down below, lying in a circle of people who talk in concerned voices as they kneel around your unconscious body. Someone is coming in the door with a wet towel or glass of water, perhaps smelling salts. Then you are back inside your own still dreadfully heavy body, looking not down but up at this assembly. It is over, and you are not very sure all of a sudden where you have been or where you are now.

Much of this dream-often described in similar terms by those who have "died" on the operating table-is easily explained as an epiphenomenon of oxygen gradually being withdrawn from different parts of the brain (those that control memory, balance, vision, etc.). Still, it does raise an almost metaphysical question. Since the dreamer never reaches the bottom of the height from which he falls, does that mean that the experience of consciousness endlessly protracts itself during its final seconds?

Pat Sheeran then told a story about a time he almost died, the occasion of an unforgettable two-way talk with God. His life had had many phases. He had been a public-action anarchist, then a union organiser. He had become an expert on the botany and topography of the Burren. He had been and still was a mushroom-gatherer. And during one phase, he had 
been a wind-surfer. All the time he would be in Galway Bay or round the coast of Clare in the gales and big waves. Once out beyond the Flaggy Shore, the sea became so angry it tore his sail to pieces. Each wave heaved him high and threw him low, carrying him all too quickly toward the rocky headlands. If he was not drowned first, there on the shore he would surely die, smashed and bloody and full of seawater. Terrified, he called on God. I will give up anything, just save me! No answer. I'll give up drink! No answer. And cigarettes. No answer. Then the voice of God shaped itself in his mind. Will you give up Nina? No, he replied, I would rather die and go to hell. I will not give up Nina.

- So you see, he said across the dinner table to Nina, I am going to go to hell for you.

He never did tell me how he got out of that stormy sea. Perhaps it was by the same route he has by now surely gotten out of hell.

\section{3}

Subsequently, he told me that for a long time he never went to Mass. Latterly, he had experienced a desire for a return to Catholic worship. Perhaps it was hearing the banshee cry in a Tennessee hotel room the night his father (an ex-policeman) died in Navan. But Pat Sheeran could not just start showing up for the eleven o'clock mass at Galway Cathedral. He had a beef with the Bishops of Galway, for he claimed they either fattened on church funds, fathered unacknowledged children on American women, or supervised the mistreatment of students in boys' schools. So Pat Sheeran located a priest in town who had returned from Africa with a wife and children. The hierarchy had ordered this priest to separate himself either from the wife or from the Church. He would do neither. He was saying pre-Vatican II Latin Mass on Sunday mornings in Le Graal, a wine bar on Dominick Street. The majority of the congregration were, oddly, nursing mothers. I should go sometime, Pat suggested. After all, I kept talking about scholarly books on the historical Jesus.

No, Mass attendance fitted my life at no point. I was not Catholic or Christian, or even ex-Christian, just a natural-born pagan with an interest in the religious beliefs of my fellow humans. But what about a counterproposal-we would write a book together called Bad Catholics. A "bad Catholic" was a rebel from either the clergy or the dogma of the Church, 
but whose spiritual relation to the world was through and through a Catholic one. A bad Catholic would have a Catholic sense of sex, a Catholic sense of beautiful magic, a Catholic sense of confession, and a Catholic sense of sacramental realities like purgatory, marriage, and lustration. A bad Catholic might sleep around or busy himself in the black economy but he would not eat fish on Friday. Pat Sheeran asked which of us would write what in this book-presumably, I'd do George Moore since I had written a long biography of that author. No, Moore was not a Catholic at all, good, bad, or indifferent. My part would be to write the life story of Pat Sheeran, and Pat Sheeran could take his pick of the rest...say, James Joyce, for instance, the quintessential bad Catholic. The title would be a winner. Soon people would realise that the only kind of real Catholics left are bad Catholics, and that perhaps the best Catholics of all earlier eras were bad Catholics too because they had their doubts and were not always obedient.

The project never came to anything, I think because Pat Sheeran had a Catholic sense of humility and so declined to be the hero of a story. Probably he also sniffed something morbid about me writing his life before he was done writing it and living it himself. Besides, the only books with which he would be associated would be, he explained, the works of Nina Fitzpatrick. Still, I think it would have been an excellent subject. A church in which Pat Sheeran was again made at home would be a desirable institution for any country to have.

\section{4}

A few years ago he showed me a script for a short film by Nina Fitzpatrick. I wish I still had a copy of it. It opens with a spaceship landing on the treeless moonlit stony hills of the Burren. Out of it get a crowd of aliens with metalliclooking faces and big eyes. They walk about in a sort of full-body halo. Soon they assemble in a dry stone church on the Burren, and, seen from without, the church sends rays of light through all the unmortared cracks. Inside, the aliens are being given a sermon by the local parish priest. He is delighted at the rise in Sunday attendance. He dreams of extending his mission to the stars and the million undocumented species of the universe. From having been priest to the smallest parish of Ireland, he will carry the torch to the universe, like the great Irish saints of the past! 
The priest explains to his extraterrestrial congregation that God loves all creatures. Smiles appear on the faces of the aliens. They are a touchyfeely species, quick to be tickled by an idea, and quick to give the kiss of peace. Next the priest explains the Ten Commandments.

- There is one God and no other-the One who loves all creaturesand you must worship Him.

They squeal with delight; they would be glad to do so.

- Next, you shall not make graven images, or any other pictures of the Divine One.

Fine.

- Don't take the name of God in vain.

By smiles and noddings, the aliens show that they would never curse anyone.

- Next, come to Church every Sunday and don't work on that day.

Excellent! The commandments about honoring parents and avoiding murder also go down very well, and the aliens are concluding that at last in their travels through the universe they have come upon the Truth. Then the priest goes on to the Seventh Commandment:

- You shall not commit adultery.

Adultery? What is that? That, explains the priest, means that you marry a person of the opposite sex and then you may kiss, hug, and sleep with no more than this one person. The aliens are in a flutter. The noise of strange converse rises in the Burren church. One of them is delegated to ask a question: what would be the result of ignoring this particular commandment? That would be terrible, answers the priest: God would no longer love you; He would be angry; He would cast you into the fiery pit. Close-up here on the face of one alien: a large blue tear forms in the corner of an eye, and then rolls down a titanium cheek. One by one the members of the congregation arise from their pews, and, as the priest begs them to stay for further explanation, they file out of the doors of the church.

The whole film is rather complicated, as it involves the hilarious troubles of a County Clare kangaroo farmer. I cannot remember the details. What I do remember is the general idea Pat Sheeran communicated of a Roman Catholicism that had been reformed by Martian sensibilities, so that all were once again welcome within it. 


\section{5}

Pat and Nina were going for dinner at Dave Power's house (he is a filmproducer in Galway, and he had the script about the extraterrestials in County Clare). Pat was bright-eyed about this approaching dinner engagement. Did the chances for funding look promising? No, that was not it. It transpired that Dave Power, himself a hunk, has a beautiful wife, Therese a reflexologist). I had to understand: everything Therese did was beautiful. To be around her was to be decentered: you fell right out of your own ego. It was all one could do to keep from staring, but one felt the need to memorize this face. As in that book by Elaine Scarry On Beauty and Being Just, the "homely act of staring" was an urge toward replication, a desire to copy, and become like her or to make something like her (Scarry 1998: 7). She attended to you, to everyone, with grace. You felt honored to have been noticed in a kindly way. Pat concluded by telling me he always felt much better for a day or two after having dinner with Dave Power.

He made it clear that Therese was not something or someone he wanted. If he could have anyone, he already had that person, Nina. And playing the thief with another man's wife-Dave Power was the best of men and a friend at that-was entirely out of question. Besides, such goings on would be the furthest thing from the mind of Therese. Fulfillment of sexual desire was not at issue. To act as beautifully in relation to the world around you as she did, and to have such an improving effect on every event that passed-those effects would be worth replicating, if one could somehow catch from her the trick of it.

Cliodhna was not sure that this form of male regard was not simply a classic case of the objectification of women. At first, I was inclined to agree, but to add-so, men objectify women, men are scopophiliacs, men are hard-wired to look at women admiringly. It is evolutionary in origin. What is to be done? But then I began to think that I was not understanding Pat Sheeran's regard for another man's beautiful wife in the correct manner. He did not objectify Therese because it was not primarily her body-image that he found to be beautiful. Consider this thought-experiment: another woman of about the same size brings a photograph of Therese to a team of cosmetic surgeons. They can do just about anything, they are that sophisticated. They go to work in the operating room, and later in the gym and the hair salon; presto! Out comes another Therese. Would Pat have found her beautiful? I don't think so. It is a case similar to the one Yeats 
makes for Maud Gonne in "The Folly of Being Comforted." Not her hair, which grows grey, or her face, which becomes wrinkled, but her "ways" are beautiful to him (Yeats 1963: 86):

Because of that great nobleness of hers

The fire that stirs about her, when she stirs,

Burns but more clearly.

\section{6}

The desire to reproduce (but not to possess) is like the impulse to turn phrases or to tell stories well or to make films or, as Pat Sheeran was doing at the time, to build a house on a hill near Moycullen that people should still be glad to see on that hill in another hundred years, something beautiful. In the modern period, beauty had gotten a bad name. It came to be believed that all art should be disturbing, conceptual, outrageous, industrial, or incomprehensible. The sublime had utterly trumped the beautiful. An appealing, harmonious, pleasure-giving art was treated as a prop for the status quo; or as superficially decorative, hiding the ugly truth; or as a form of prettiness cranked out by one fashion system or another, to keep people buying and to rebuild the walls of status distinctions. Things should not be this way, for while they were, the world was getting patently uglier. You would have to be an idiot not to realise that more beauty was good, and less was bad.

But what was the beautiful, after all? I have since come to think that James Kirwan may be right in holding that beauty is not a thing at all, or even a property of things, but an experience of a thing that gives disinterested pleasure (see: James Kirwan, Beauty). Pat Sheeran did not want to get rich by writing a screenplay that would sell (while having no objection to blockbusting success as an unintended consequence); he did not want to get the woman from his friend for the sake of his own desire; he did not want to put up a house that simply provided typical comfort at the lowest price. Instead, he sought (with Nina's help) to create pleasures that were intrinsically satisfying.

Much about this quest for beauty still confounds me, and I doubt that I shall ever understand it. In a New Symposium conducted with the dead, Pat Sheeran may be sorting the matter out with Socrates, Dante, Blake, 
Kant, Oscar Wilde, and God. Socrates could explain the move from the beauty of the boy to Beauty itself to the One that is the True, the Good, and the Beautiful too. Dante could show the way up the same long stairway from the beauty of Beatrice to the Beauty and Truth of God, expressed as light and the song of angels. Since the $19^{\text {th }}$ century, we are more likely to halt on the stair, and falter where we firmly trod, and stretch lame hands and grope, and gather dust and chaff (Tennyson 1849: poem 55). "What is to be done with this newfound knowledge," a contemporary philosopher asks, "that in beauty, behind beauty, is nothing, the abyss, dust?" Is it that we still need to know God but there is no God; we still seek Truth but there are only truths; we search for the soul but we are only animals able to dream up the concept of soul; we want eternity and yet there is less time left for each of us with each day we live? Right down the line, we do not get what we most want. Yet, amazingly, in the one case of beauty, our experience of being just out of reach of the Ultimate is an experience of pleasure.

According to Kant's way of thinking, in the moment of gazing upon something that is to us beautiful, we do not feel that this beautiful thing is a thing of its cultural moment, or that its attraction springs from our own particular taste, or that reverence for it masks the contradiction at the heart of the landowning class. In the moment of apprehension of beauty, we forget all the relative and material aspects of the experience. We feel, as Kirwan observes, that we have entered into something "universal," and that others may share in that experience.

Yet people, in fact, do not all find beauty in the same things. There are communities of taste, groups of people who find pleasure in the fact of finding pleasure all together from a single source, and who find pleasure as well in talking about what is best or a little less than the best about that common source of pleasure. The communities overlap sometimes, and sometimes not at all (perhaps one cannot enjoy both Mozart and heavy metal). Beauty inspires in communities of taste a bit of missionary zeal. To feel that this is beautiful and that, by God, is not, is to feel righteous. One is supposed to be just as tactful about not denouncing a friend's décor to the friend's face as about not talking down that friend's religious beliefs in the sanctuary of the friend's presence. Apart from this little sphere of tolerance and tact, people are as passionate about their convictions in matters of taste as in matters of faith. 
Even if the great souls in the symposium were to agree that beauty is a feeling, not a thing; and that beauty creates an illusory belief that one is in the presence of the universal; and that in fact communities of taste are all equally unjustified in their missionary righteousness; even if all this were true, as a paid-up member of the Pat Sheeran community of taste, I have my own zeal for the good news. There are, I believe, particular grounds for what is beautiful to humans. The grounds are not, as Socrates, Dante, and Kant suggest, in God, Truth, or Metaphysical Universals. They are (Eureka!) the following three:

Nature,

The human body,

What the Greeks called techne, or skill in making.

No natural landscape is unbeautiful. I have travelled across North America, China, Europe, and everywhere one finds oneself among other humans travelling and admiring the landscape. A rich and lively swamp in Ontario is full of beauty; so are the exotic bodily shapes of hot Mohave sanddunes. The earth may be found in an ugly state where humans have blighted it, but pretty much only there. Each tree is beautiful. So is each leaf. So is the chequered shade upon the lawn. Forms of art draw their sense of variety, shape, harmony, and texture from our experience of this planet. The seasons created by this revolving planet in its revolutions around its sun create our sense both of cyclity and of the four-phase staged progress to an apex and down from that apex. As Northrup Frye showed in the 1960s, there is a genre, a trope, and a mode of expression for each season. There are few comedies of autumn or tragedies of springtime. The primitively-conceived four elements-water, earth, air, and fire-are constituents in the psychology of the spirit: there is a mood and personality type for each. This planet is our home; we love all its variable elements and trace in them the lineaments of beauty. When humanity saw the first pictures of the earth taken from outer space, the response was to hail its extraordinary beauty, compared with that of red Mars or even manyringed Saturn. Those other planets were strange icy forms of beauty in the universe, but not warm, domestic, lovely, cloud-enswirled, blue-oceaned home, Gaia. Everyone thinks of the earth as a female and a mother; not so with Mercury, Mars, Jupiter, Saturn, Uranus, or Pluto. 
Second, "the Human Form Divine," as Blake called it, is the source of many canons of beauty. Symmetry centers us. We like organic relations of parts to the whole, with a higher (the head) and lower (obedient limbs, disobedient parts too). According to Edmund Burke, as infants at the breast, we are imprinted with an idea of beautiful form. The line that is drawn from under a woman's ear, down along the neck, over the collarbone and plunging in the swoop of the breast is the "line of beauty." Our concept of the sublime, he implies, is derived during same early stage of life from the remoteness, erectness, height, capacity for anger, and strength of the father. An extraterrestial species-let us say one that looks like an opposum-might find our species an off-putting sight, but for us, even a human of 'average' endowment is the image of God. It is a difficult lesson in the Book of Job when the voice in the whirlwind declares that God is also the whale and the crocodile, "the doors of his face with his terrible teeth all around" (41:14). The easiest forms of beauty in which to take pleasure are the primal, narcissistic ones, those that hold up the mirror to humanity, and especially to motherhood.

Finally, we stand in awe of the person who can do what God is said to have done: make a world by means of skill and superabundant power. We like it when the handiwork shows, and we like it when the handiwork is hidden in the independent perfections of the thing made. We like it when the creation has a history (includes the image of time past and time passing) and we like it when artifice creates a world that seems either timeless or not yet come to pass. There are so many good reasons for this satisfaction with the human capacity for creation that they cannot all be spelled out. One thing above all we use as a mark of the best kind of making. That is the kind of making that was done so well we say the thing was made to last. A person that writes a poem or a play not to please the largest number of consumers now, but to satisfy the dead and the still unborn, that is the person to whom in the end we yield up our honors. Before they died, the great writers aimed to leave, and did leave, "something so written to after times as they should not willingly let it die (Milton 1642)."

Right now, of course, for the most part those who provide the pleasures for kingdom come may get as much praise as Jesus got when he went home to his neighbors, brothers, and sisters in Galilee. They said he was a madman. He could do no mighty works there because of their unbelief (Matthew 13: 56-58). Thus was the prophet without honor in his own country. Outside Galilee, people loved a miracle-the walk on the water, 
the resurrections, the changing of water into wine. And they loved the miracle-worker who defied all odds. But the Palestinians evidently were also set on fire by the way Jesus had of telling old stories in new ways, such as the one about the kingdom being like a man who found a treasure in a field (not his own field), and went away and sold all that he had, so that he could buy that field; that is what the kingdom of heaven is like. Jesus was great with riddles.

- Now what is the kingdom of heaven like? You cannot guess? It is like a mustard seed.

- And how is that?

Let me tell you...

He was not an ordinary storyteller, or barefoot doctor, or defrocked priest working at the riverbank. It was hard to know what to call him. Even within his own time, people were inclined to follow him and to praise his mysterious power and the specific talent for making people see the earth as heaven on which they should live like angels.

\section{7}

A few months after Pat Sheeran died, word went out that there was to be a gathering in his honor at Le Graal one Thursday evening. The people who came on that night were remarkably in their variety. One was a lighting technician with a television crew. "I only saw him once," the technician said. "I was on assignment to do the lights for a television interview of Nina Witozsek, to be held in the wooden house out the Moycullen way. We were all set up with all our lights downstairs when this man appeared up on the overhanging balcony. He asked us if we had everything we needed. We could make free with the refrigerator if we were hungry or thirsty. Then he disappeared into an upstairs room. The funny thing about it was that he was completely naked. I concluded that Pat Sheeran was a man very comfortable with his own body."

There were, of course, students and professors-plenty of them. The Classics professor Brian Arkins gave a furious rendition in perfect Latin of Catullus V: "Vivamus mea Lesbia"-Let us live, my Lesbia-which totes up the scores, then hundreds, and thousands and hundreds of thousands of kisses the poet would give his beloved. There were also gardeners, housebuilders, mushroom gatherers, film directors, film and theatre people of 
many sorts, political activists, and a reflexologist. On the whole, there were more women than men. Everyone came to praise the lively spirit of Pat Sheeran.

It is good to praise men and women, particular people who have gone a journey no one else has gone, people who have left a proof of their being in the memory of friends, or on paper, or on film, or in gifts they have given, houses they have built, children they have raised, or relationships that they have created. I am thinking especially of people who widen our sense of human possibility by adding to the world's store of what is beautiful. It is a pleasure to praise Pat Sheeran.

\section{References}

Kirwan, J. (2001). Beauty. Manchester: Manchester University Press.

Matthew 13: 56-58 http://www.biblegateway.com/passage/?search= Matthew $+13 \% 3$ A56-58\&version $=$ KJV

Milton, John. (1642). Introduction, The Reason of Church-government. http://www.dartmouth.edu/ milton/reading_room/reason/book_1/ index.shtml

Scarry, E. (1998). On Beauty and Being Just. Cambridge: Harvard University Press.

Tennyson, Alfred Lord. (1849). In Memoriam, poem 55. http://www. online-literature.com/tennyson/718/

Yeats, W. B. (1963). The Collected Poems. London: Macmillan.

Received: 15 July, 2011

Accepted for publication: 25 September, 2011 


\section{Едриен Фрејжер}

\section{ЉУДИ И ЛЕПОТА}

\section{Сажетак}

Овај аутобиографски есеј у славу ирског романописца, режисера и научника Пета Ширена (Pat Sheeran), поставља следећа питања: „Чему служи ово новостечено знање у лепоти, које изван лепоте не представља ништа, амбис и прах?“ Које су форме писања и живљења довољне у нашем времену, кад је теорија исцрпла све расположиве залихе обнављања у култури које су биле доступне ствараоцима у прошлости, док су смрт и бесциљност представљају неумитност као и некад? Истражујући необичну, шаманску природу Пета Ширена, овај есеј испитује истрајност стваралачког надахнућа лепотом, љубављу и уметношћу.

Кључне речи: Пет Ширен, роман, филм, лепота, ништавило, писање, смрт, бесциљност, уметност 